\title{
Healthy Breakfast on Learning Concentration of Junior High School Students
}

\author{
Reni Ilmiasih*, Nur Lailatul Masruroh, Dini Ramulia \\ Department of Nursing, Faculty of Health Science, University of Muhammadiyah Malang, \\ Jalan Bendungan Sutami 188A Malang 65145 \\ *Corresponding author: reni@umm.ac.id
}

\begin{abstract}
Background: Healthy breakfast is a complete morning menu consists of first food, side dish, vegetables and fruits and also drinks. Healthy breakfast provides students cognitive performance and gives energy for brain while learning process like learning concentration. Objectives: This study aimed to determine the effect of healthy breakfast on junior high school students learning concentration. Method: This study used a pre-experimental One-group pre-post test design. Samples were 21 students junior high school taken with purposive sampling. The research instrument is a concentration test Army Alpha. Results: a significance level of 0,036 ( $p<0,05)$ which means that there is the effect of healthy breakfast on students learning concentration and the differences between the average score of focus level before and after consuming healthy breakfast are 0,71. Conclusion: Healthy breakfast is one way that can improve the concentration of learning in children. Breakfast affects cognitive performance by providing essential nutrients for brain.
\end{abstract}

Keywords: Healthy Breakfast, Learning Concentration, Junior High School Students

\section{INTRODUCTION}

The concentration of learning is a process of focusing attention and simple codingeducation that is doing a meaningful exploration and transfer of knowledge from the source of learning for the next development. Attention or concentration helps one to choose and focus on an object that is important and defend it in a period (Kuswana, 2011). Children need attention to concentrate on a lesson so that it can have an impact on behavioural changes that are appropriate to the learning objectives.

School children often experience the problem of learning concentration. Wood (2007), said nearly 4 million schoolchildren suffer from learning difficulties that are about $20 \%$ of them have difficulty concentrating. Children who are difficult to concentrate often daydream excessively and quickly disturbed when trying to focus attention on a thing. Research on the low concentration of study in Indonesia such as the study conducted by Sujaya, Sulastri and Suranata (2013) showed that most students in grade VII C SMP Negeri 2 Seririt have a low learning concentration of 44\%. A study conducted by Prasanti (2015) in Grade VIII Government Junior School 16 Surakarta shows that 33 students have alowlevel of study calculated by Army Alpha $\leq 4$ test score.

Based on the results of observation when the learning took place by researchers on February 8, 2016, in class VII A and VIII Aneight students do not concentrate during the lesson and when asked about what has been explained by the teacher students cannot answer the question correctly. Researchers conducted interviews to classroom teachers about student achievements such as the value of daily tests and tasks; there are some students whose value is less than Basic Competence (KD) so given additional tasks and 
remediation. The children who experienced learning difficulties in the classroom as many as four people $(6.5 \%)$, seven people $(11 \%)$ remedial.

Center for Disease Control (CDC) (2014) states that one of the factors that affect the concentration of children's learning in school is the pattern of healthy and regular food consumption such as breakfast. Non-breakfast students associated with decreased cognitive performance in schools such as attention or attention, memory, problem-solving and decreased complex visual appearance abilities. The hunger for not having breakfast and the lack of eating vegetables and fruits associated with learning outcomes, attendance, repetition and inability to stay concentrated while studying.

The difficulty of learning in school is influenced by the ability to focus. Learning and concentration problems cause the child cannot digest well what is described by the teacher so that it can affect a person's learning outcomes. Littleeducation results will also affect the child psychologist. Children who are difficult to concentrate and have little learning outcomes tend to blame themselves and feel pressured about the effects of education is not satisfactory (Surya, 2009).

The result of a preliminary study has done by the previous researcher on students of SMP Muhammadiyah 06 Dau Malang.The result of this research was 28 people (46\%) breakfast on $24(73 \%)$ ate rice and side dish. Twostudents $(6 \%)$ rice and vegetable, students $(6 \%)$ drank milk, two students $(6 \%)$ eat instant noodles, two students $(6 \%)$ eat bread, people (3\%) drank fruit juice, and 33 people (54\%) did not have breakfast.Breakfast has an important role in nourishing the tired brain and need the energy to get back on the move. These nutrients can be as diverse as carbohydrates, vegetable and animal proteins, fats, vitamins, minerals and nutrients that used for intelligence development such as DHA, choline and prebiotics as well as micronutrients. Proper and balanced nutrition is an essential element in supporting the development of students' intelligence at school (Smart \&Supardi, 2014).

Studies conducted by Prime and Hardinsyah (2013) show that only $10.4 \%$ of school-aged children are sufficient for energy and consume healthy foods at breakfast. Based on the data of Basic Health Research (RisKesDas) (2013) East Java province shows that as much as $90 \%$ of East Java people consume fewer vegetables and fruits as essential nutrients for school-aged children, especially if consumed at breakfast. Suggests that many school-aged children who do not consume enough energy and healthy breakfast are eating fewer animal foods, vegetables and fruits.

The previous study by Lazzeri et al. (2013) showed that students who did not have breakfast regularly had a low frequency of vegetables and fruit consumption supported by studies carried out by Fatmah (2010).Appocymetly 28\% of middle school teenagers with iron deficiency due to lack of vegetable consumption resulting in a decrease in cognitive or intellectual power, learning achievement and low work productivity capacity. Use of a healthy breakfast in addition to increasing the frequency of consumption of vegetables and fruits that can avoid iron deficiency also improve the ability of student concentration in school.

Breakfast is a food consumed in the morning after a night of fasting or not eating. Breakfast provides an important role for the body in providing energy and nutrition before starting daily learning activities. Children who do not have breakfast will feel tired, lethargic and challengingin concentrating because in the breakfast provides energy and essential nutrients such as iron, calcium and vitamins B and C are necessary for growth and development. School children who do not have breakfast tend to eat less healthy snacks such as high fat, sweet and salty so it can also increase the risk of overweight or obesity. 
Defeyter and Russo (2013) in his research on The Effects of Breakfast Cereal Consumption on Cognitive Performance and Mood in Adolescents explained that breakfast affects the young school. This study conducted by giving breakfast treatment in 1 day then performed cognitive performance test. The results of the tests in this study indicate that breakfast can help children to concentrate on doing tasks and can contribute to improving the mood like a feeling full and fit so ready to receive lessons in the morning.

The role of nurses in helping the fulfilment of national goals by encouraging the formation of a healthy lifestyle, including regarding nutrition. School-aged children who are undergoing educational programs are important to get the nutrients appropriate their growth and developmental stages to improve their learning process and success (Poeter\& Perry, 2009).

\section{METHOD}

The research method used in this research is pre-experimental design using one group pre-post test design. This study conducted by observing the groups before treatment and after treatment using Army Alpha Test.

The population in this study is the seventh-grade students of SMP Muhammadiyah $06 \mathrm{Dau}$, Malang reported by counselling teachers have concentration problems in learning in the classroom. The sampling technique used in this research is purposive sampling method. The sample in this research is the students of class VII of the total of 3 classes VII SMP Muhammadiayah 06 Dau, Malang. The sample is taken based on the criteria specified by the researcher and the perception equation between the researcher and the teacher by looking at the class characteristics in which the majority of students have problems in concentrating based on cognitive behaviour, affective behaviour, psychomotor behaviour, language behaviour. Students who have a history of certain diseases such as diabetes mellitus and gastritis and potential health problems resulting in a concentration disorder excluded from the sample criteria, as well as students with a history of food allergies to served.

This research conductedin August for twodays, the first day for pretest and second day of giving of treatment at the same time post-testcarried out at SMP Muhammadiyah 06 Dau, Malang. Bivariate analysis to see the difference before and after treatment using paired $\mathrm{T}$ test with thecondition of normal distribution data, the second group of dependent data of digital type.

\section{RESULT AND DISCUSSION}

Table 1 shows the age distribution of respondents on the average age of 13.33 years. Sex distribution is mostly male. Parent's education level almost half of high school. Average distribution of the mean value of the ordinary mathematics subject is 37.39 , while the average daily value of Indonesian items is 73. The breakfast habits of more than half of the respondents are not accustomed to breakfast. Sleep patternsbalanced between less and enough with percentage almost half. 
Table 1 Respondents by Age, Gender, Mathematics Score, and Breakfast habit at Students of SMP Muhammadiyah 06 Dau, Malang in September 2016.

\begin{tabular}{|c|c|c|c|c|c|c|c|}
\hline No. & Characteristics of Respondents & $\mathbf{N}$ & $(\%)$ & Min. & Max. & Mean & SD \\
\hline 1. & Age & 21 & $100 \%$ & 13 & 15 & 13,33 & 0,658 \\
\hline \multirow[t]{3}{*}{2.} & Gender & & & & & & \\
\hline & Male & 19 & $90 \%$ & & & & \\
\hline & Female & 2 & $10 \%$ & & & & \\
\hline \multirow[t]{5}{*}{3.} & Education parents & & & & & & \\
\hline & Elementary school & 5 & $24 \%$ & & & & \\
\hline & Junior school & 5 & $24 \%$ & & & & \\
\hline & HighSenior school & 10 & $47 \%$ & & & & \\
\hline & Bachelor & 1 & $5 \%$ & & & & \\
\hline \multirow[t]{3}{*}{4.} & Index presentation & & & & & & \\
\hline & Average Mathematics Score & 21 & $100 \%$ & 23 & 63 & 37,39 & 11,30 \\
\hline & Average Bahasa Indonesia Score & 21 & $100 \%$ & 50 & 90 & 73,00 & 9,375 \\
\hline \multirow[t]{3}{*}{5.} & Habit of breakfast & & & & & & \\
\hline & Yes & 7 & $33 \%$ & & & & \\
\hline & No & 14 & $67 \%$ & & & & \\
\hline \multirow[t]{4}{*}{6.} & Adequacy Sleep & & & & & & \\
\hline & Less sleep & 9 & $43 \%$ & & & & \\
\hline & Enough & 10 & $48 \%$ & & & & \\
\hline & More sleep & 2 & $9 \%$ & & & & \\
\hline
\end{tabular}

\section{Concentration Level of Junior High School Students before Healthy Breakfast}

Results of Measuring Concentrations of Student Learning Before Giving Healthy Breakfast. The result of a study of student's attention in SMP Muhammadiyah 06 Dau, Malang, is measured using Army Alpha test sheet. The result of research focuson student learning before giving healthy breakfast can see in table $2 \& 3$ below:

Table 2. Distribution of Junior High School Student Concentration before Healthy Breakfast Delivery on 21-22 September 2016.

\begin{tabular}{llc}
\hline Student Concentration & $\mathbf{f}$ & Prosentase (\%) \\
\hline High Concentration & 0 & $0 \%$ \\
Medium Concentration & 1 & $5 \%$ \\
Little small Concentration & 5 & $24 \%$ \\
Low Concentration & 6 & $28 \%$ \\
Very low Concentration & 9 & $43 \%$ \\
\hline total & 21 & $100 \%$ \\
\hline
\end{tabular}

Table 3. Student Concentration After Healthy Breakfast

\begin{tabular}{lccl}
\hline Group & Before breakfast & After breakfast & Average \\
\hline Mean & 2,29 & 3,00 & 0,71 \\
\hline
\end{tabular}

Table 2. shows the results of the measurement of the concentration of junior high school students before obtaining healthy breakfast in getting data as much as nine children $(42 \%)$ have low concentration level once one child $(5 \%)$ have medium concentration level. The results in Table 3 shows that the average value for pretest is 2.29. The concentration level of junior high school students is mostly very low because this is because the concentration of junior high school students influenced by several factors such as age and 
gender. The age of respondents in this study was in the range 13 years to 15 years with the average respondent aged 13 years.

The level of study concentration of junior high school students is mostly low. Itinfluenced by several factors such as age. The result of the survey of the students' concentration level is still low is owned by 17 respondents who are at the age of 13 years as many as 14 respondents and three respondents at the age of 14 years. Respondents aged 13 and 14 years including early adolescents (Fatimah, 2008). The theory by Plummer (2012) that one of the factors that influence the ability of student's learning concentration is age because followed by growth pattern. Younger children are harder to concentrate than older children because they are more often adapt actively with disorders and more focused on the task. Research by Loher, Sarah and Roebers (2013) suggests that younger children have less inhibition or impediment and motor control impairment than older children with switching ability or adaptation response capability to better environmental change. Junior high school students including early adolescents who are in a period of increased growth one of them is a cognitive change. Piaget mentions that children at this stage are at the formal operational stage because they can predict a possibility, sort it out, solve problems, and make decisions through logical thinking (Poeter\& Perry, 2009). Learning difficulties experienced by many school children are almost 4 million, or as much as $20 \%$ of them have difficulty to focus attention (Wood, 2007).

Another factor affecting student concentration is the educational background of the parents. Parents can exert influence in the form of behaviour and decision making done by the students they can. Parents with higher education and income backgrounds can provide better facilities and environments for their children so that the motivation to learn increases and affects the child's academic performance and achievement (Chevalier, et al., 2013). Respondents in this study have parents with an educational background that is low enough that elementary school (SD) of $23 \%$. It is possible to contribute to the low concentration of learning before breakfast.

\section{Level Concentrations Student Learning After Healthy Breakfast}

he result of the level concentration of junior high school students in SMP Muhammadiyah 06 Dau, Malang is given healthy breakfast in table 4.

Table 4. Distribution of Junior High School Student Concentration After Healthy Breakfast Delivery on 21-22 September 2016

\begin{tabular}{llc}
\hline Student Concentration & F & Prosentase (\%) \\
\hline High Concentration & 1 & $5 \%$ \\
Medium Concentration & 1 & $5 \%$ \\
Little small Concentration & 7 & $33 \%$ \\
Low Concentration & 4 & $19 \%$ \\
Very low Concentration & 8 & $38 \%$ \\
\hline total & 21 & $100 \%$ \\
\hline
\end{tabular}

Based on the results of the measurement of the students' concentration of SMP Muhammadiyah 06 Dau, Malang after giving a healthy breakfast found that children $(38 \%)$ had very low concentration, one child $(5 \%)$ had averageconcentration and one child (5\%) had a high concentration. Result of Analysis of Healthy Breakfast Influence on Student Learning Concentration SMP Muhammadiyah 06 Dau, Malang in Figure 1. 


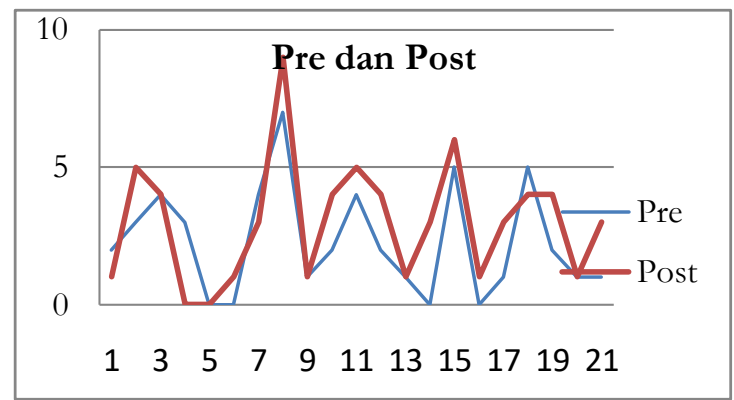

Figure 1. Measurement Results Concentration Level Before and After a Healthy Breakfast

Based on Table 4. from 21 respondents found that there is an increase in the concentration level of respondents after being given a healthy breakfast as much as 2 respondents have a high concentration and 19 respondents have a low concentration. Increased concentrations of dominant concentrations occur in children who have low scores once become low and rather low.

Several factors influence the low concentration that is still owned by the respondent. Factors are one of them is age. Younger age tends to be harder to concentrate because of growth and development factors that occur (Nuryana \& Purwanto, 2010).

Other factors that influence the concentration of learning include the environment (Surya, 2009). Byoung-suk (2012) states that the environment is one of the factors that affect the development and learning of children. Time spent at school 6-8 hours gives effect to the formation of children's intellectual ability. A supportive and fun school environment makes children more comfortable and concentrates on their academic activities. A fun and adequate school environment provide the stimulus needed for a learning experience. A noisy or dense environment can affect the concentration and achievement of student learning outcomes. Schools with comfortable facilities and environments can increase students' motivation to learn so that students become more concentrated (Usaini \& Bakar, 2015). The respondent's school environment is a relatively dense environment because there are two schools, namely elementary and junior high so that it can affect the ability of student concentration.

Another factor that can influence the concentration of learning is the physical condition (Nuryana \& Purwanto, 2010). The status of students will affect the concentration of learning such as tension and fatigue that causes the brain to experience energy deficiency so that the intake of oxygen and blood flow to the brain was not optimal. When the brain is deficient in energy, the brain is not functioning optimally and can cause a decrease in student learning concentration (Prasanti, 2015). Physical condition factors can see from the sleep patterns of students. Students when asked bedtime most sleep late. Insufficient sleep time may interfere with student motivation and interest in the classroom. Students become difficult to receive information because less sleep time causes sleepiness and fatigue. Drowsiness can make it difficult for children to receive information and record it in memory, so it also affects the ability to concentrate when learning. Theory by Dimitriou (2015) that sleep plays a major role in the healthy development of children and adolescents. Sleep supports both physically and neuro-biologically in academic learning and cognitive function. Optimal sleep associated with a better academic performance that is the concentration of learning.

Breakfast is foodconsumed in the morning because not previously eat for 8-10 hours. Breakfast at school children contributes $20-25 \%$ of energy needs in a day. Breakfast is important to recharge the body's energy and nutrition before starting daily activities. Breakfast is a special food for the brain and provides benefits in restoring the body's 
metabolic functions. Breakfast is closely related to mental intelligence and provides a positive value for brain activity; the brain becomes more intelligent, sensitive and easier to concentrate. Breakfast gives a positive influence on school children in the activity (Ministry of Health RI, 2011, SA Health, 2009, Feeney, 2013).

Breakfast can improve behaviour and feelings by helping children concentrate better and not feel tired because of hunger. Eating breakfast can help children have better academic performance and improve some behavioural problems in adolescents. Research shows breakfast is closely related to health status and increased the ability to learn. The quality of food in children affects cognition, and nutrition is less associated with absence, hunger, and psychosocial problems. Breakfast gives a child a chance.

\section{The Effect of Healthy Breakfast on Student Learning Concentration}

Table 5. the T test results using SPSS version 21

\begin{tabular}{ll}
\hline & Before-After \\
\hline $\mathrm{T}$ & -2.251 \\
Asymp. Sig. (2-tailed) & .036 \\
\hline
\end{tabular}

Based on result of $\mathrm{T}$ Test analysis by using SPSS program obtained $\mathrm{t}$ value = 2,251 with significance level $0,036(\mathrm{p}<0,05)$, Sig value. (2-tailed) < real level $(\alpha)$ and H1 conclusion can be accepted which means that there is theinfluence of Healthy Breakfast to Learning Concentration. When viewed from the average score of the concentration level of student learning before and after a healthy breakfast there is a difference in the average number of student concentrations of 0.71 . The level of student concentration after a healthy breakfast is higher than before a healthy breakfast.

The concentration of learning requires the process of selecting the quality of the planned by developing interest, motivation and attention or concentration on the object of learning. Developing the ability of focus takes a short time between starting with maximising readiness and good study habits. Less than optimal readiness due to lack of nutrition and hunger can also affect the concentration of one's learning (Surya, 2009). The ability of one's concentration can attempt to enhanced with healthy and regular exercise and diet (Fortenbaugh, 2015, CDC, 2014).

Healthy breakfast is one way that can improve the concentration of learning in children. Breakfast is a food consumed in the morning in charge of providing energy for the brain filled with glucose transported into the brain through the blood-brain barrier (Barasi, 2009). Breakfast affects cognitive performance by providing essential nutrients for brain and hunger. Lack of energy causes glucose and insulin to drop to a sufficient level, followed by impaired brain function. Around 10 to 12 hours between thelastdinner followed by not consuming breakfast resulted in low glucose levels thus affecting cognitive performance. If the energy supply to the brain is less and often occurs, then it could have an impact on school performance in the long term (Adole et al., 2015).

Eating a healthy breakfast is a diet that consists of staple food sources, side dishes, vegetables and fruits and drinking water is sufficient and complete can affect a person's cognitive performance. Food in the digest from the mouth to the stomach takes \pm 2 hours to get to the small intestine and then channelled into the bloodstream to all body tissues that require adequate nutrition. Mixing foods with stomach acid, mucus and pepsin, then produced components of carbohydrates, proteins, and fats. Carbohydrates are then digested in the stomach into more simple parts such as glucose while the protein is broken down into amino acids and fats. Foods have metabolised by the liver channelled throughout the circulation of the digestive tract that absorbs nutrients through the portahepatic vein. Food 
will be stored in the liver and used when the body occurs nutrient deficiency. Carbohydrates, fats, amino acids, storage of vitamins and minerals stored in the liver and will use when the body occurs nutrient deficiency. Carbohydrate metabolism by the liver to stabilise blood sugar, so nature is aconstant condition. If the blood sugar decreases then the liver cells will break the deposits of glycogen into glucose into the blood circulation and vice versa. If there is a shortage of fat reserves will be broken down and the result into the blood circulation. Fatty acids can be converted into fat and glucose to stored as energy reserves. Vitamin A, D, E, K, and vitamin B12 absorbed from blood are stored and then reused if needed by the body (Tarwoto, Aryani, Wartonah, 2009; Syaifuddin, 2009).

The brain requires energy derived from carbohydrates, proteins, and fats found in foods and beverages. The human brain is metabolic very active and used as much as $20 \%$ $30 \%$ of food intake while solving the problem. This lack of need will lead to changes in mental function such as by not eating breakfast. Carbohydrates in foods are needed as energy in the form of glucose as a precursor neurotransmitter to receive stimuli from outside information (Mergenthaler, et al., 2013).

Glucose metabolism provides power for physiological brain function through ATP as a basis for the balance of neuronal cells. Proteins are needed to help the formation of brain structures. Amino acids by various carriers (transporters) that penetrate the bloodbrain barrier. Amino acids help the formation of highly sensitive neurotransmitters to the food components of serotonin, dopamine and norepinephrine to reduce hunger and increase mental consciousness and energy. Fat has a major rolein the brain. Fat helps the formation of acetylcholine. Essential for memory and mental function. Low levels of acetylcholine will have an impact on aging, memory loss and decreased cognitive function. Vitamins and minerals derived from vegetables and fruits provide antioxidant benefits and significantly help reduce in neural and cognitive function. A healthy diet consisting of a variety of food sources can help nourish the brain and mood, energy and cognitive function (Turner, 2011; Barasi, 2009).

Another similar study related to breakfast for junior high school children is a study conducted by Garg, Rajesh and Kumar (2014) entitled to determine the influence of breakfast on nutritional status and school performance. The results of this study indicate that breakfast can affect learning performance that is on the concentration and recall memory of children in school. It is due to decreased levels of glucose and hunger for not having breakfast. Akitsuki et al. (2011) breakfast influenced NBLF (Nutrition Balanced Liquid Food). Consists of carbohydrate, fat, protein, vitamin and mineral with sugar water, and water only to fMRI (Magnetic Resonance Imaging) and UK cognitive function test, as well as N-back test with protocol experiment, was done by concentration test 2 hours after breakfast consumption using UK test. The results obtained were increased activation in the brain and concentration after the respondent consumed a healthy breakfast with a full menu component (NBLF) compared to water and sugar water. Another study also related to breakfast conducted by Perez and Preciado (2014) revealed that school children who are aware and knowing a healthy breakfast with good quality have better academic performance than the less.

\section{CONCLUSION}

The concentration level of junior high school students before being given a healthy breakfast mostly has alow category. This low concentration is due to several factors: age, gender, parent education, interest and low student learning motivation. Level of junior high school students' concentration after being given a healthy breakfast has increased. Increases occur in low to moderately low and moderate categories. It is due to the 
provision of a healthy breakfast with a full menu consisting of rice, vegetables, side dishes, fruit and drinks. The paired $\mathrm{T}$ test analysis showed that the research hypothesis was accepted which means the provision of healthy breakfast affected the concentration of student learning in SMP Muhammadiyah 06 Dau, Malang with the difference of the average score of 0.71 . The mean concentration scores after the provision of a healthy breakfast increased when compared with the mean score before the distribution of a healthy breakfast.

\section{REFERENCES}

Akitsuki, Y., Nakagawa, S., Sugiura, M., Kawashima, R. (2011).Nutritional Quality of Breakfast Affects Cognitive Function: An fMRI Study. Neuroscience\& Medicine, 2, 192-197.

Caro, G.C., Perez, L.M.L., \& Preciado, V.G. (2014). Analysis of Knowledge about Healthy Breakfast and Its Relation to Lifestyle Habits and Academic Performance in Compulsory Secondary Students. Endocrinology Nutrition Journal, 1-10.

Chevalier, Arnaud.,Harmon, Colm.,Sullivian, Vincent O'., Walker, Ian.(2013).The Impact of Parental Income and Education on the Schooling of Their Children. IZA Journal of Labor Economics, 2(8).

Defeyter, M..,\& Russo, R.(2013).The Effect of Breakfast Cereal Consumption on Adolescents' Cognitive Performance and Mood.Infrontier Human Neuroscience, Department of Psychology, Northumbria University and University of Essex, NewcastleuponTyene, UK, Essex, 7,1-10.

Feeney, M.J (2013). Breakfast Good Nutrition ThroughoutLife.Health Connections 1(2), $1-4$.

Kementerian Kesehatan RI. (2013). Riset Kesehatan Dasar Jakarta :Badan Penelitiandan Pengembangan Kesehatan.

Kementerian Kesehatan RI. (2011). Strategi Nasional Penerapan Pola Konsumsi Makanan dan Aktivitas Fisik untuk Mencegah Penyakit Tidak Menular. Jakarta: Direktorat Jendral Bina Gizi dan Kesehatan Ibu dan Anak.

Kuswana, W.S. (2011). Taksonomi Berpikir.Bandung : PT RemajaRosdakarya.

Lazerri, Giacomo., Pammolli, Andrea., Azzolini, Elena., Simi, Rita., Meoni, Verobica., Wet, Daniel R. de., Giacchi, Mariano., Vincenzo.(2013).Association between fruits and Vegetables Intake and Freuquency of Breakfast and Snacks Consumption: A Cross Sectional Study. Nutrition Journal, 12:123.

Loher, Sarah.,\& Roebers, Claudia M.(2013).Executive Functions and Their Differential Contribution to Sustained Attention in 5- to 8-Year-Old Children .Journal of Educational and Developmental Psychology, 3(1).

Mergenthaler, P.,Lindauer, U., Dienel, GA., Meisel,A.(2013).Sugar for the brain : the role of glucose in physiological and pathological brain function.Trend Neuroscience, $36(10)$.

Nuryana, A. \& Purwanto, S. (2010). Efektivitas Brain Gym dalam Meningkatkan Konsentrasi Belajar pada Anak. Jurnal Ilmiah Berkala Psikologi, 1 (5), 88-99.

Potter \& Perry. (2010). Fundamental of Nursing: Buku 1 Edisi 7 . Jakarta: EGC.

Supardi\& Smart, A. (2014). Ide-Ide Kreatif Mendidik Anak Bagi Orang Tua Sibuk.Jakarta : Kata Hati.

Surya, H. (2009).Menjadi Manusia Pembelajar.Jakarta: PT Elex Media Computindo.

Tarwoto.,Aryani, Ratna., Wartonah.(2009). Anatomi dan Fisiologi untuk Mahasiswa Keperawatan. Jakarta: Trans Info Media 
Turner, Julia. (2011). Your Brain on Food : A Nutrient-Rich Diet Can Protect Cognitive Health. Journal of American Society on Aging, 35(2).

United States Department of Agriculture. (2009). Energize Your Day! 2Eat School Breakfast: Serving a Healthy Breakfast. USDA. 